\title{
Democracy, \\ Constitutionalism and the Rule of Law: \\ Beholden to Constituent Power
}

Ivan Sage

2/3/2014

FACULTY OF LAW

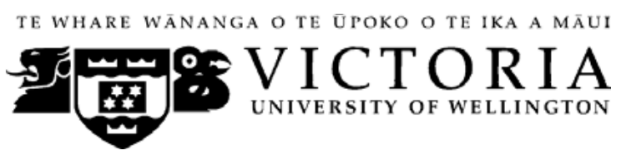




\section{Democracy, Constitutionalism and the Rule of Law:}

\section{Contents}

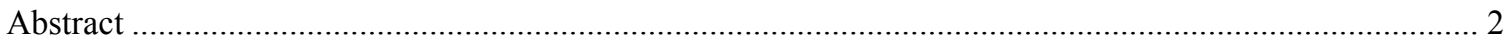

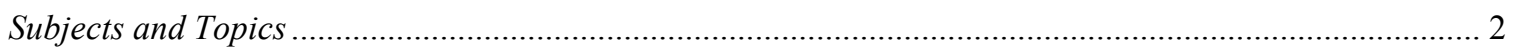

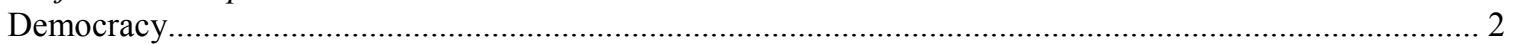

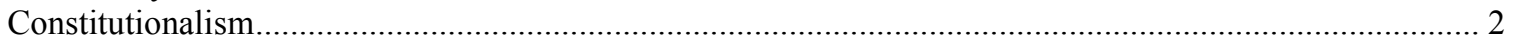

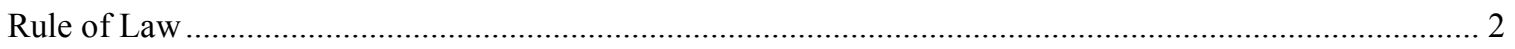

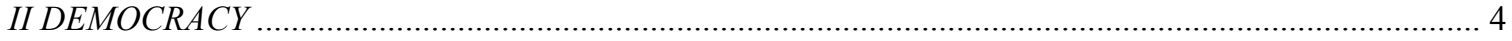

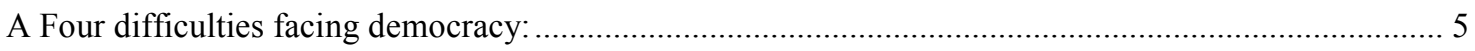

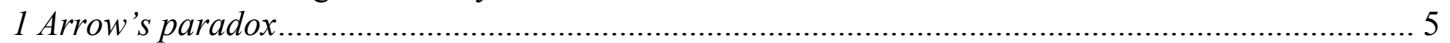

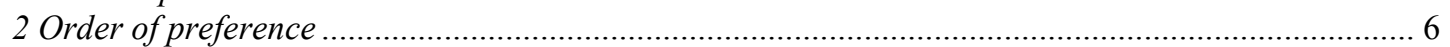

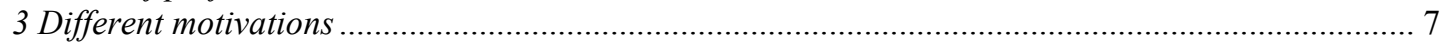

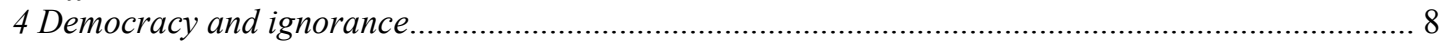

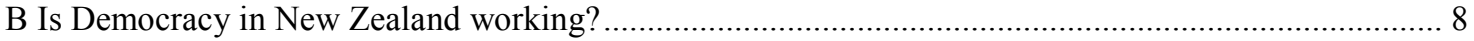

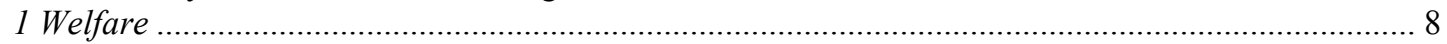

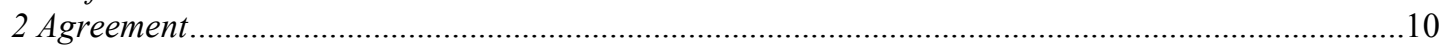

3 Autonomy

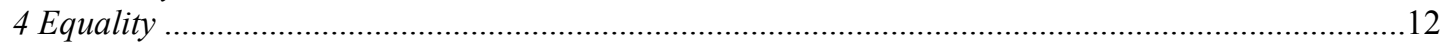

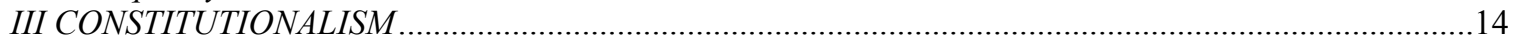

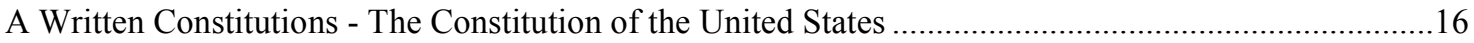

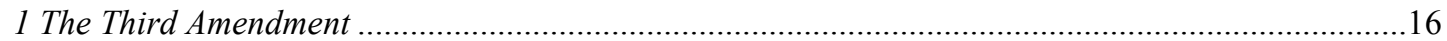

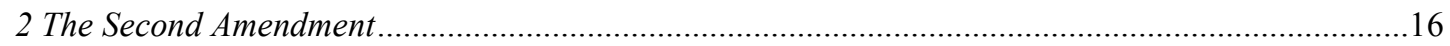

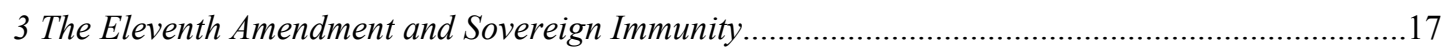

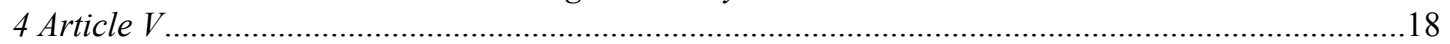

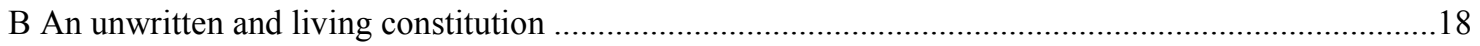

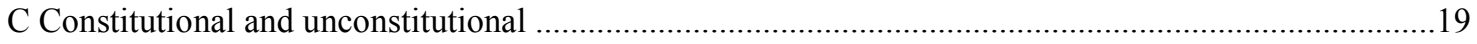

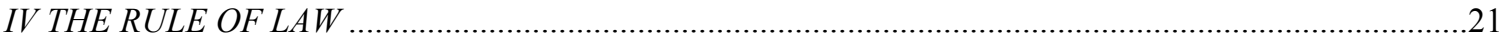

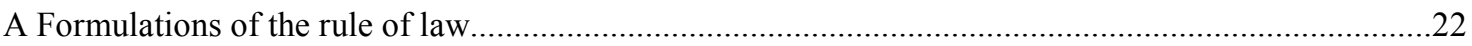

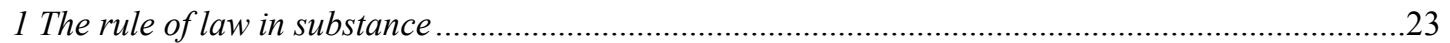

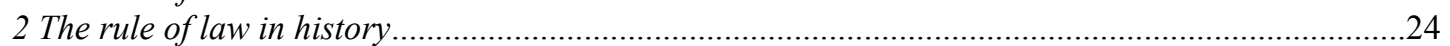

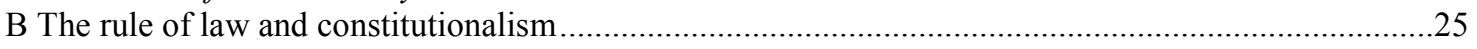

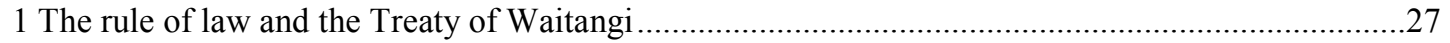

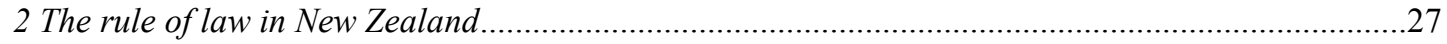

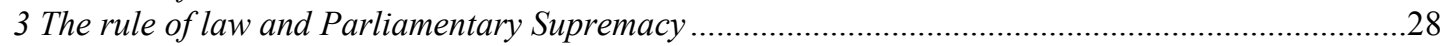

4 The rule of law, or, as a necessity of the Right of the House ..............................................................29

V DEMOCRACY, CONSTITUTIONALISM AND THE RULE OF LAW: BEHOLDEN TO CONSTITUTENT

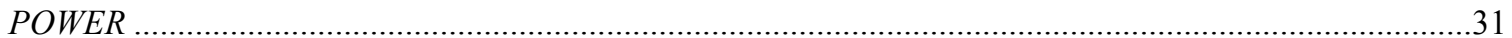

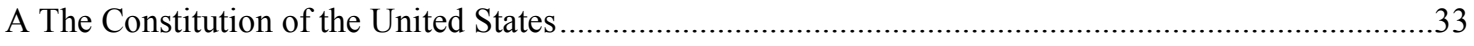

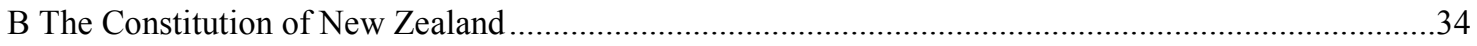

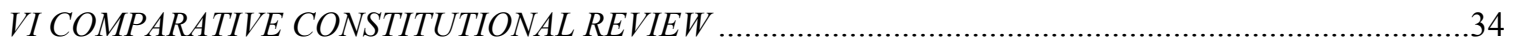

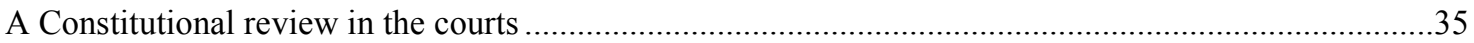

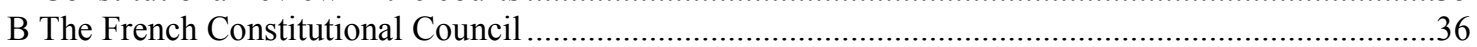

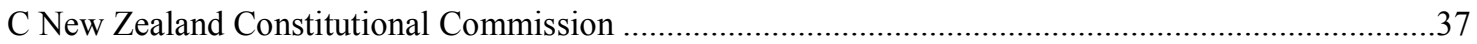

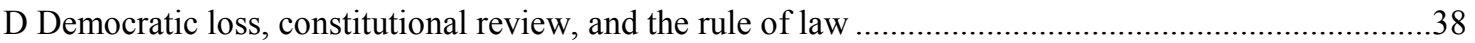

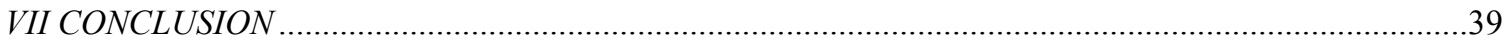

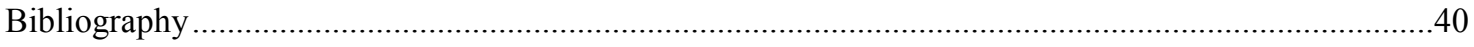




\begin{abstract}
Democratic government serves two purposes, both requiring that the substantive element of the rule of law be adhered to. A living constitution is required by a government to able to maintain civil society, which is the main occupation of the rule of law and, secondly, the rule of law also vouchsafes rights and freedoms. Hence, the rule of law enforced by the courts is the factor that controls the constitution, and increasingly this includes controlling the government, both the legislature and executive. This paper considers the capacities of democracy, constitutionalism and the rule of law, in the context of both New Zealand's unwritten and America's written constitutions, with the view of locating the constitution making power (constituent power). The power that makes and changes the constitution was originally found with the people, parliament, and the executive. However, a modern formulation of the rule of law that seeks to replace parliamentary supremacy as the ultimate principle of legality appears to be arising. An egalitarian society is becoming the preferred option by all parties. In this context, the constitution making power will be with the vessel that is working towards creating such a society. To that end, the paper recommends a Constitutional Commission for New Zealand that would review legislation for constitutionality, including adherence to the rule of law. The objective of the Constitutional Commission would be to recommend the review of law for constitutionality, including adherence to the rule of law.
\end{abstract}

\title{
Word Length
}

The text of this paper (excluding the abstract, contents page and bibliography) comprises approximately 15858 words.

\section{Subjects and Topics}

\section{Democracy}

Constitutionalism

Rule of Law

Constituent power 


\section{Democracy, Constitutionalism and the Rule of Law:}

\section{INTRODUCTION}

Different formulations of democracy will bring about slightly different results, and so too of course will different constitutions, but a government committed to democracy and constitutionalism will tend to have respect for the rule of law; there is a direct relation between these three. This paper will develop the idea that the three separate theories of democracy, ${ }^{1}$ constitutionalism ${ }^{2}$ and the rule of law ${ }^{3}$ are flawed, face difficulties when redistributing power and are not yet fully adhered to; however, together the three theories make a seemingly consummate whole.

Democratic government serves two purposes, both requiring that the substantive element of the rule of law be adhered to. Firstly, via a constitution the government is able to maintain civil society, which is the main occupation of the rule of law and, secondly, the rule of law also vouchsafes rights and freedoms. ${ }^{45}$ Hence, the rule of law enforced by the courts is the factor that controls the constitution, and increasingly this includes controlling the government, both the legislature and executive. ${ }^{6}$ As will be seen in the discussion on the quintessence of the rule of law, there is a challenge being made against parliamentary supremacy, which results in a nation's constitution being a preferred product of the rule of law and this endeavour will result in peoples' constituent power ${ }^{7}$ (constitution making power) becoming predominant, as a opposed to legislative or executive constituent power. The objective of this paper is to describe where the constitution making and maintaining power now lies, whether with parliament or the people, or rather is it in transition.

Beginning with democracy, in part II, the paper will look at some criticisms from an economic theory perspective, to indicate where the imperfections are in the theory. A further justification for democracy is that it generally serves welfare, agreement, equality and autonomy. ${ }^{8}$ Part III has an overview of constitutionalism focusing on a few differences between conservatives and liberals, to indicate if and how constitutions can

1 The Oxford Companion to Philosophy, edited by Ted Honderich, (Oxford University Press, New York, 1995) 183.

2 Philip Joseph Constitutional and Administrative Law in New Zealand (The Law Book Company Limited, Sydney, 1983) 1.

${ }^{3}$ See Joseph, note 2, at 167.

${ }^{4}$ Philip Joseph Constitutional and Administrative Law in New Zealand (The Law Book Company Limited, Sydney, 2007) 152

${ }^{5}$ Authors note: I was working between two editions of Philip Joseph's text book Constitutional and Administrative Law in New Zealand, (the 1983 and 2007 editions) and while in the main this paper relies on the 2007 edition, for an earlier draft of this paper, I relied upon the 1983 edition.

${ }^{6}$ Note 4 above, at 151

${ }^{7}$ I am indebted to Joel Colon-Rios for the background discussion on constituent power, the political power that exists in the legislature, executive and people to create and amend a constitution.

${ }^{8}$ Note 1 . 
contain a government. The unwritten and living constitution of New Zealand is compared with the written Constitution of the United States to demonstrate how those constitutions that are able to change, staying relevant and cognisable with the evolving intellectual and moral responsibility of the citizens, will be endurable. The rule of law, a component of constitutionalism, is the important element in any society, and in Part IV the concept is developed as the source of all civil liberties and common law rights, including, arguably, constituent power. ${ }^{9}$

Part $\mathrm{V}$ brings these three components together in a discussion on how a government, committed to democracy and constitutionalism, will also be continually committed to the rule of law. The element of constituent power, which can be found in various forms in the three components, appears to ameliorate the flaws, difficulties and lack of adherence with the three, democracy, constitutionalism and the rule of law, respectively, so that these three blend together to make a stable society. Constituent power exists in a democracy, when citizens determine which rights they wish to retain, it also exists in a constitution which limits for example the amount of state intervention that a government can exert, and in the rule of law constituent power exists as the ultimate power to determine who is supreme, the rule of law or the rule of a sovereign parliament. ${ }^{10}$ Part VI compares the French and American jurisdictions with regards to constitutionalism, with a comparative of different models of constitutional review in the courts, to determine an appropriate model for constraining political power and discern how the review of the constitutionality of legislation might be obtained, within the unique New Zealand political culture. The paper recommends a Constitutional Commission for New Zealand that would recommend the review legislation for constitutionality, prevent parliament from adopting an unconstitutional law and the decisions of the Constitutional Commission will be judicially reviewable in the ordinary courts of the land.

\section{DEMOCRACY}

Winston Churchill's well known quip was "that democracy is the worst form of government other than all of the other forms that we know" 11 and that is an appropriate reflection upon democracy. Few would regard democracy as complete. If democracy is the worst form of government, other than the other forms which are worst still, then this discussion is about what would make democracy become better, perverse as this may sound. A better democracy must be a contradiction in terms, because a better democracy requires more decision making by a minority of elected representatives.

Democracy is most commonly described as government by the people. ${ }^{12}$ In a

9 Joel I. Colon-Rios Carl Schmitt and Constituent Power in Latin America Courts: The Cases of Colombia and Venezuela (2011) 18 Constellations 365.

10 Note 2, 152

11 Note 1, 184

12 Note 1. 
democracy, all adult citizens and often including immigrants are able to participate in a process, where voting takes place to elect representatives, who decide on policies. ${ }^{13}$ Usually a formula, such as mixed member proportional representation, is required for a democracy, relating representation of electors to political parties. Popular preferences to represent the people and political outcomes are often difficult to coincide, but generally choices for candidates are made on likely outcomes. ${ }^{14}$

Society may be in a good state, while the democracy running it is in an unstable one. This could be the result of members crossing the floor of the House of Representatives when voting, some unfavourable policies, poor choices of candidates, and even indecision amongst the members of parliament. Nevertheless, there are some recognised justifications for democratic rule: it provides procedures for dealing with a variety of interests; when individuals participate in a democratic process they gain some autonomy, even empowerment; there is widespread political equality produced by a government which is gained through the political process; and, discussions and deliberations on policies and legislation produces a natural form of consent. ${ }^{15}$

\section{A Four difficulties facing democracy:}

\section{Arrow's paradox ${ }^{16}$}

However, democracy has some difficulties. The first is that individual preferences do not aggregate into collective preferences. Kenneth Arrow ${ }^{17}$ has written on social choice theory, and broadly speaking, social choice theory is dependent on the ability to aggregate individual preferences into a combined preference. This economic theory of Arrow's, unfortunately for democratic theory, directly translates across; so, with respect to individual choices or preferences, they do not aggregate into collective or combined

\footnotetext{
${ }^{13}$ Note 1.

14 Note 1.

15 Note 1.
}

16 "Arrows paradox [is a] paradox in social choice theory. Why not devise a function that orders options for a society in terms of the preference of is individual members? Such a function would have to meet certain conditions on reasonableness - such as that (a) an ordering could be obtained by any logically possible set of individuals' preferences, (b) if everyone prefers a given A to a B, then that A should be ordered above that $\mathrm{B}$, (c) no individual can dictate the social ordering - there can be no individual such that whenever he prefers an A to a B, then that A must be ordered above the B, and (d) the ordering of any A and $\mathrm{B}$ depends on the individual preferences between that $\mathrm{A}$ and $\mathrm{B}$ alone. Arrow proved that there was no consistent function which met all of the conditions." The Oxford Companion to Philosophy, edited by Ted Honderich, (Oxford University Press, New York, 1995) 58.

17 Kenneth Arrow's General Possibility Theorem states that when voters have three or more alternatives or options no rank order voting system can convert the preferences into a community wide ranking while also meeting a specific criteria. See: Social Choice and Individual Values by Kenneth J Arrow (John Wiley and Sons, Inc, New York, London 1951). 
preferences, because these preferences can be too difficult to define. The individual preferences for such utility functions as funding for better schools and more frontline police are for utilities that are not measurable by the same yardsticks. One person may prefer better schools, while another wants increased policing. But, personal preferences for utility functions like schools and policing are immeasurable - requiring differing yardsticks to do so - and it is impossible to determine which utility function is the best use of resources and money. Arrow's study showed there is "no consistent function from individual preference to collective choice." 18 The study showed how the impossibility theorem worked. When passing from individual to collective choice or taste, there does not appear to be any method that satisfies the condition of rationality. ${ }^{19}$

\section{Order of preference}

Further, Arrow's studies also showed a second difficulty, that voting will give different outcomes for preferences depending upon the order that the options are presented. What appears to be unanimous amongst political theorists is that there can be no perfect voting system. ${ }^{20}$ The voting paradox shows that the "preferences obtained by majority voting between pairs do not give a coherent ranking." ${ }^{21}$ People vote for an outcome depending upon the order in which the options are presented.

Arrow uses as an example a community of three voters, who have to choose between three alternate modes of social action; his options were disarmament, cold war or hot war. ${ }^{22}$ His voter's paradox shows that the rational outcome for the three choices, disarmament, cold war, or hot war, will depend on the order in which they are presented to the three voters. There is no reliable method for determining an outcome and satisfying the condition of rationality. ${ }^{23}$ When going from individual preferences to collective outcomes, there is no rational outcome for any preference, other than the order in which the preferences are presented. If the preference of a 'hot war' is presented first, that would be preferred. As Arrow put it, "[a]ssuming that any acceptable function must meet a small number of intuitive conditions ... there is no consistent function from individual preference to collective choice." ${ }^{24}$ A democratic society could choose a 'hot war' if that was the first choice of the three options presented to society, even though they do not want one. It is not possible to formally construct a procedure to pass from individual

\footnotetext{
${ }^{18}$ Note 1 , at 58

${ }^{19}$ Kenneth J Arrow, Social Choice and Individual Values (John Wiley and Sons, Inc, New York, London 1951) 3 .

${ }^{20}$ Note 1,904

${ }^{21}$ At 903

${ }^{22}$ Note 19 , at 2

${ }^{23}$ Note 19 , at 3

${ }^{24}$ Note 1 , at 58 
tastes to social decision making. ${ }^{25}$

Responding to these concerns, one might say that "democracy might not be determinate, even though individual preferences might be." ${ }^{26}$ That is saying that democracy does not need to have any exact and discernable limits, or form, even though an individual's preferences might be exact and discernable. Democracy can be indeterminate; not exactly known, nor established, nor defined, without a definite or definable value, perhaps not even absolute, while personal preference can still be definite. ${ }^{27}$ There might be personal political preferences that are not absolute, nor definite, however, the goods that democracy produces like civil liberties, a stable society and common law rights are absolute and definite.

\section{Different motivations}

A third difficulty for democratic theory is that individual voters may be motivated differently and these motivations are incompatible with the collective preferences and voter's paradox problems noted above. Anthony Downs ${ }^{28}$ introduced a left - right axis for economic theory, placing communists to the left, and conservatives to the right. He then showed how people use this axis to decide whether they think there should be government intervention in an economy and also, how different parties will control this, and therefore which political party to vote for. Choosing a political party on how much intervention the party will have in an economy is completely incompatible with the individual preferences of Arrow's above, which are immeasurable. ${ }^{29}$ A political party can have a considerable amount of intervention in an economy, however the individual preferences for utility functions will not necessarily have been aggregated into collective preferences, so that none of the decisions made upon preferences are being translated via the intervention into the economy, by the chosen political party. There is a double flaw because there is no relationship between the intervention in the economy by a political party and personal preferences for utility functions, which are immeasurable.

This third difficulty is harder to respond to. A person can decide upon how much government intervention they want to see in an economy and therefore which political party to vote for, without knowing anything about the economy, nor the political parties, and neither the relationship between the two. Political decisions can be made with ignorance and very little or no intelligence. The motivation for voting in a democracy can come from a perverse logic, which undermines the justification for democratic rule. ${ }^{30}$

\footnotetext{
25 Note 21 , at 2

${ }^{26}$ Note 1

${ }^{27}$ Concise Oxford Dictionary Eleventh Edition (Oxford University Press, New York, 2004) 390.

28 See Anthony Downs, An Economic Theory of Democracy (New York, Harper, 1957).

29 Note 1, 183

${ }^{30}$ Note 1,183 


\section{Democracy and ignorance}

Downs also has an account of how much time and effort a person can be expected to apply when informing themselves on democratic matters, and this amounts to a fourth difficulty. Rational citizens, he argues, should keep the cost of political information down to a minimum. ${ }^{31}$ For Downs to be correct there must be no state control of the media and the same political information should be available to all. Voters (he says) are largely ignorant and will act irrationally. ${ }^{32}$ There is time involved in processing political information, perceiving, assimilating and thinking about it, which Downs says is a scarce resource. He suggests that "the costs of gathering, selecting, transmitting, analysing, and even evaluating data can be shifted to others. ${ }^{\prime 3}$ This would leave the public with one remaining choice, to simply believe the political information that is being passed onto them, and to exercise their democratic right accordingly. Downs firstly attributes ignorance to the public and secondly concludes that people largely do not know who to vote for.

\section{B Is Democracy in New Zealand working?}

New Zealand is committed to democratic rule. As Jeremy Waldron has said, roughly, every man and woman has the right to participate in the resolution of a disagreement, where a common decision is needed. ${ }^{34}$ When Parliament's intention is made clear, whatever has been enacted in the legislature, the courts in New Zealand have no power to neither invalidate nor decide otherwise. Elected representatives, after assessing and securing the public interest of the majority of voters, ${ }^{35}$ produce legislation that is passed through parliament, but the will of the majority should not be allowed to prevail when fundamental rights are being breached. There must be consent, creating political obligation, which is binding upon the citizens to obey the laws.

According to Russell Hardin, in western democracies like New Zealand, democracy should serve four purposes: welfare, agreement, autonomy and equality ${ }^{36}$ each are discussed briefly below.

\section{Welfare}

Whether the state has the duty or function of looking after the well-being or welfare of its people is often a contested discussion in a western democracy, but similarly so too can state surveillance and the need to keep a standing army in times of peace be

\footnotetext{
${ }^{31}$ Note 28,220

32 At 221

${ }^{33}$ At 222

34 Jeremy Waldron "The Constitutional Conception of Democracy" in Law and Disagreement (Oxford University Press, New York, 1999) at 283.

35 Sir Jeffery Palmer, Referendums endanger our democratic system, in Dominion Post, 24 December 2013, A11.

${ }^{36}$ Note $1,184$. 
matters for discussion. Western liberal democracies are more focused on political freedoms than economic equality and welfare because supposedly the market can determine when to produce more houses, better education, jobs and wealth. The question as to whether the state has a duty towards the welfare and wellbeing of its citizens is often resolved by saying there should be minimum state interference in welfare, in keeping with a principle of the rule of law.

Welfarism is the view that assigns to the state the function of looking after the welfare or wellbeing of the people. ${ }^{37}$ Whether this extends to economic sufficiency, education, employment, housing, including the basic needs of food, clothing and warmth as a matter of social justice requires further consideration. The difficulty for the opponents of welfare is that it is hard to justify inequality of wellbeing. Welfarism does have a utility function: welfare is a good in itself, like wellbeing, and there are preferences for where money on welfare can be spent, the options include, health, education and housing. The International Covenant on Economic Social and Cultural Rights $^{38}$ in Article 9 recognises the right to social security, social insurance, and in Article 11 "adequate food, clothing and housing, and to the continuous improvement of living standards." ${ }^{39}$ The covenant goes on to say that the state "will take appropriate steps to ensure the realisation of this right." ${ }^{40}$ However, the full realisation of these rights and indeed the right to wellbeing has never been fully actualised.

Barbara Cruikshank writing in "The Will to Empower"41 says that democracy creates power and those for example that become dependent upon welfare that are disempowered, develop their own techniques for resolving these power imbalances. Welfare creates dependency. Those dependent on welfare outsmart the subsystem by becoming involved in cottage industries and developing their self-sufficiency. ${ }^{42}$ Powerless to represent themselves, those who are dependent on welfare are referred to by conservatives as ones who have had the moral fibre sucked out of them, because of their dependence upon welfare. ${ }^{43}$ Dependents upon welfare develop some resourcefulness and while they still carry responsibility for their actions, without the resources of a full income, they do not reach their fullest potential.

Welfare, as a part of a democracy, is particularly problematic in the current political climate, with the Global Financial Crisis and the need for governments to be

\footnotetext{
${ }^{37}$ Note 1 at 908

${ }^{38}$ International Covenant on Economic Social and Cultural Rights (opened for signature 16 December 1966, entered into force 3 January 1976) Articles 9, 11.

${ }^{39}$ Note 38

${ }^{40}$ Note 38

${ }^{41}$ Barbara Cruikshank The Will To Empower: Democratic Citizens and Other Subjects (Cornwall University Press, New York, 1999) 108.

42 Note 41 , at 108

${ }^{43}$ Note 1 at 908 
fiscally prudent. The other argument is that in a recession, the government needs to fulfil its obligation by providing welfare to maintain a stable society and prevent the social decline that results from poverty, which becomes evident in the likes of child abuse, the decline in mental health and increases in crime. Largely the political masses' consent to welfare is causal upon their opportunity for participation in the voting system. In the current fiscal environment, this opportunity for the masses to consent to changes in welfare is unavailable because the form of democracy does not allow for direct participation on matters such as welfare and equality.

When referring to welfare in a democracy what it often being contested is whether there is being further development of the nanny state? The opponents of welfare may conclude that such endeavours are a part of the agreement that citizens make when they form themselves together into a state. This pragmatic view sees the people's views of democracy as productive of all sorts of goods, not all of which everyone is in agreement with.

\section{Agreement}

Consistency and harmony are the by-products of agreement. Democracy encourages agreement. Citizens, by giving consent to what has been decided by their representatives in parliament who are acting out of equal concern and respect for all, have agreed to the polices and decisions made by the legislature. Democracy facilitates for the citizens of a state to deal with a variety of interests, when policies are agreed upon and then there occurs some natural form of consent to a common good.

An argument for determining where the common good lies was put forward by Dworkin. ${ }^{44}$ When referring to the 'common good' he is saying when a decision has to be made between two possible alternatives, the example he used is between basketball courts and music halls, and a community can only have one or the other, then the political process assists the legislators in agreeing on which of the goods to choose. Decisions are made upon a majority vote when a representative is deciding political issues in the legislature. As discussed above with Arrow's paradox, the individual preferences for utility functions are not measurable by the same yardstick. An electorate deciding basketball courts over music halls is making a decision for which they will never know if the other outcome would have yielded a better long term result. But they will have agreed on an outcome.

Even if the citizens do not agree on the outcome from the decision making process, their elected representatives were put into parliament by a majority vote, either as local representative or on a mixed member proportionality ticket. There is a form of consent involved, where elected representatives from an electorate are sent to parliament as delegates of the electorate and are said to be in parliament as the voice and

44 Ronald Dworkin Is Democracy Possible Here? Principles for a New Political Debate, (Princeton University Press, New Jersey, 2006) 141. 
representatives of the people.

However, representatives are known to have private or governmental interests that they would prefer, and sometimes they do not vote according to the will of their constituents, preferring some other interests. Edmund Burke, said, when speaking to his electors, "he might owe his constituents the courtesy of listening to their opinions, they had no authority to oppose instructions and mandates; ... his duty was to act for the best interest of the whole country." 45 There is so much disconnect between constituents and elected representatives that it is unlikely that the people actually agree with much of what their elected representatives have decided in parliament.

Again, Ronald Dworkin raises further questions about majority rule and the value of choosing their elected representatives by vote. ${ }^{46}$ The Athenians chose their leaders by lot, as Dworkins pointed out, and he also suggests that it is not vividly clear whether the quality of our leaders would decline because they were chosen that way, for example, drawing names from a barrel. Such a procedure, choosing political representatives by lot or chance, rather than on personal attributes, would avoid picking the most determined candidate, or the wealthiest, or the most charismatic or ambitious. Were political representation to be as a result of chance and more of a co-operative exercise, then this would be better for agreement in democracy as a principle.

\section{Autonomy}

An essential element in nation building that is implicit in a democracy is that of autonomy - a Greek word that is a derivative of "self + law. ${ }^{47}$ The individual or agent must be able to freely and rationally make moral and intellectual decisions for which they are recognised as being responsible for. The individual is sovereign over all of their choices, which extends to freedom of speech and expression, privacy; the state should not pretend to interfere in any of the desires, choices or rights that the autonomous individual seeks to maintain or in control thereof. In a democracy the individuals remain autonomous, by virtue of the fact that the government respects individual choices, so that persons can maximise their opportunities to be self-determining and realise their full potential.

Autonomy in a democracy can also refer to how an individual wishes to conduct their moral life, and on such issues a majority decision may not be necessary or appropriate. Dworkins also points this out. ${ }^{48}$ The majority should not decide if a minority, say, gays or lesbians, should be allowed to marry. They can decide that for themselves.

45 Martin Loughlin, "Constituent Power Subverted: From English Constitutional Argument to British Constitutional Practice in Martin Loughlin and Neil Walker (eds) The Paradox of Constitutionalism, (Oxford University Press Oxford 2007) 47.

${ }^{46}$ Note $44,139$.

${ }^{47}$ Note 1,69 .

${ }^{48}$ Note 44 , at 140 
Dworkin rightly asks whether a collective decision is needed or desirable on such a matter, because the decision would require those who disobey the majority's opinion to be punished. A collective decision may be inappropriate; arguably, if people should decide some things for themselves, having a vote so that a representative or collective decision is made, when it would be more appropriate to allow individuals to decide, seems manifestly unfair. ${ }^{49}$

\section{Equality}

Democracy serves equality. ${ }^{50}$ The assumption is that all men and women are created equal, they just do not all enjoy that equality. Whether democracy produces political, social, economic and legal equality is important, because equality is required in a democracy to maintain a stable society. Political inequality occurs when groups are excluded such as women or religious minorities, when social inequality occurs there is differences in status, ${ }^{51}$ economic inequality is more general or widespread and acceptable in capitalist societies, and legal inequality is essentially breaches of the rule of law - all are equal before the law. For people living together under statehood, where they are to retain political, social, economic and legal equality, democracy must provide a system for the citizens to be treated equally - the question becomes how much needs to be done to prevent inequalities from developing. ${ }^{52}$

The value that democracy has is that it prevents inequality from reoccurring. In order to maintain civil society and vouchsafe rights and freedoms, the compelling justification for democracy must be that it is capable of providing equality of legal, social, economic and political power by providing recognition of when inequality exists. Recognition of inequalities is a product or consequence of freedoms that are maintained in a democracy, such as freedom of expression and speech; these inequalities need to become publicised so that those suffering from inequalities are allowed legal representation and a voice in the media, a voice that is heard. Measuring and maintaining political power across parliament, the people and the executive may be problematic, but suffice to say, in the context of rights and equality, the justification for democracy that turns on equality, must be as a result of the extent that an executive is committed to providing "political institutions whose structure compositions and practices treat all members of the community as individuals, with equal concern and respect." 53 Equality in all forms is essential in a liberal democracy to maintain a stable civil society. ${ }^{54}$

\footnotetext{
49 At 140

${ }^{50}$ Note 1 , at 184

51 Note 1 , at 406

52 At 406

53 Ronald Dworkin Freedom's Law: The Moral Reading of American Constitutions (Harvard University Press Cambridge, 1996) 17.

54 Note 1,184
} 
To require a positive equality, where all persons are equally deserving of a good life is asking of the democracy to recognise that all constituents have the same or equal amount of power. ${ }^{55}$ Equality is a political ideal, something that democratic society agrees to. Similarly situated people should be treated the same. Similar treatment and how much different similarities are relevant are difficult to define. Decisions around equality of opportunity, freedoms, power, and equality before the law should not be political decisions, decided by representatives. A fully democratic society will be able to give a guarantee of equal political and legal rights. To do this absolutely, some will argue, may be impossible, impractical. Instead, ameliorating or reducing any inequalities is more consistent with the notion of democracy.

Equality in a political sense requires the individual to have a stake in the community, and an opportunity to make a difference. ${ }^{56}$ Political equality, of a kind where the people rule their officials, ${ }^{57}$ will give rise to a positive equality, such that equality will be across a broad base, includes power sharing and will give rise to the types of equality mentioned above. Back in 1642, Charles I, when his powers were being circumscribed or shared with the parliament, was concerned that "any attempt by Parliament to destroy this balance and subvert the fundamental laws of this kingdom will 'beget external factions and dissensions ... since so new a power will undoubtedly intoxicate persons who were not born to it." 58 Power was being shifted from the King to the King in Parliament, and now further since, power is being reset in equilibrium with the people. This shift in power, as political will, is bringing out that age old tension between democracy and constitutionalism, power that exists in the state of nature, ${ }^{59}$ quoting Sieyes, being returned to a state of equilibrium with the people.

Equality before the law, of political power, of opportunity, of freedoms and respect is perhaps bringing the concept of equality in a democracy closer to that proposed by Ronald Dworkin; equality has to be protected in a democracy by the country's constitution. If all persons are equally deserved of a good life, ${ }^{60}$ a democratic society should try and facilitate this, then the point of democracy is to elect representatives who will carry this vision to its natural fruition.

Democratically elected leaders must, therefore, be those representatives who have a collective vision of social, legal, political and economic equality. As a convention, this could be achieved by including in the member's oath of allegiance upon taking up office as parliamentarians, a commitment to creating an egalitarian society. This convention would become a part of the countries evolving constitution.

\footnotetext{
${ }^{55}$ At 248

${ }^{56}$ Note 53 , at 24

${ }^{57}$ Note 53 , at 28

${ }^{58}$ Note 45 , at 32

${ }^{59}$ Carl Schmitt Constitutional Theory (Duke University Press, Durham, 2007) 128

${ }^{60}$ Note 1,248
} 


\section{CONSTITUTIONALISM}

There are two main doctrines of constitutionalism; one is that constitutionalism relates to what is foundational in a government which is its history, structuring, and functioning, ${ }^{61}$ while the second relates to what is regulatory about a government ${ }^{62}$ - that a government is regulated in accordance with the law. ${ }^{63}$

The latter doctrine is that what is constitutional concerns what can regulate or limit a government, such as rules, conventions and procedures that a government has to abide by to be legitimate. Examples are found in the substantive norms, like the rule of law, written bills of rights, what people are entitled to do as in democratic rights (an example is equality, above), and these have been said to define what is legitimate in terms of political activity. ${ }^{64}$ The constitution regulates a government by placing limitations upon power, these are the substantive calculations that regulate power, that is, the rule of law, and there are also procedural calculations that limit government to follow due process, for example when enacting legislation.

The former doctrine, that the constitution is a foundational document, is the doctrine that constitutionalism can lead to the establishment of new regimes, and also to the foundation of new states, the most often used example of this being the Constitution of the United States. In New Zealand what is expressed as a constitution can be found in the principles of the Treaty of Waitangi, the founding document, various legislation (statutes of English and New Zealand Parliaments) ${ }^{65}$ conventions, laws and the customs of Parliament, and has as its most enduring feature its adaptability. ${ }^{66} \mathrm{Hence}$, it can be said that a government is a creature of its constitution, and a constitution is something antecedent to a government. The people constitute the government, a government needs a constitution to maintain its power, the constitution not being an act of the government but of the people. ${ }^{67}$ What is constitutional, therefore, is an act that both the government and the people agree to, and an act of political power that is unconstitutional is an act that the people are not in agreement with. The foundational and regulatory doctrines, at first brush, appear to be opposites, at least, in contradiction with each other because one seemingly gives to the government the capacity to govern, while the other detracts from or reduces that same capacity.

Constitutional doctrines have been further developed by the likes of Stephen

\footnotetext{
${ }^{61}$ Note 4,1

${ }^{62}$ Note 1 at 159.

${ }^{63}$ Note 1 at 159 .

${ }^{64}$ Note $1,159$.

${ }^{65}$ Note 1 , at 159.

${ }^{66}$ Note 2, at 3 .

${ }^{67}$ Louis Henkin and Albert Rosenthal, eds, Constitutionalism and Rights: The Influence of the United States Constitution Abroad, (Columbia University Press New York, 1990) 2
} 
Elkin and Karol Soltan to be inclusive of economic efficiency and informed democratic control. These writers suggest that a new form of constitutionalism is developing that requires the polity to consider the more general wellbeing of its citizens and to include some social justice. ${ }^{68}$ This would take constitutionalism beyond merely controlling the arbitrary exercise of power. Soltan discusses the place of constitutionalism versus that of the revolutionary state, discussing if constitutionalism is as appeared to Thomas Jefferson, that if every nation needs a revolution, from time to time, to reorganise or reconstitute the nation's constitution ${ }^{69}$ then for Soltan, ${ }^{70}$ this process results in a right to left pattern in which revolutions typically shift in political arrangements. Whether any revolution is more likely to be the result of a written constitution, because an unwritten constitution will lend more to allowing for social change and therefore avoid mini revolutions, will be touched on briefly below.

Constitutional changes can occur when threats of a revolution cloud over a state. If a revolution aims to determine some political limits, and popular constitutional change attempts to do the same, then governments would tend to want to avoid mini revolutions by allowing incremental constitutional changes that are directed at controlling the government's power. For a constitution to regulate a government and be a foundational component or document it needs to lie outside of politics; the power to regulate and control a government must lie in the nation, and the people. With the power to regulate a government, on the liberal view, lying outside of politics, that power also needs to achieve its ends by political means. That is, the constitution must be able to be amendable to meet popular needs, and deal with modern qualms. Politicians tend to try to create and control the constitution; the constitution, in turn, tends to try and control then recreate the polity.

Liberals associate constitutionalism with the regulation and limitation of government, ${ }^{71}$ which often requires a written constitution to be able to do so. There lies the problem within the New Zealand context; how might our constitution limit government, when it is largely unwritten? Conservatives do not have such a problem with an unwritten constitution, because they interpret constitutionalism as the practices of government, and while these practices are continuing to evolve, there is no need for any of these practices of government to be in any way limited or regulated. Limiting the practices of government would stop them changing and therefore in turn slow or limit the evolution of a constitution, so that it is no longer a living organ. A state's constitution should provide both a stable society and allow for its citizens to develop as moral and

68 See: Stephen L. Elkin and Karol Edward Soltan A New Constitutionalism: Designing Political Institutions For a Good Society (University of Chicago Press, Chicago, 1993).

${ }^{69}$ Edgar Z Friedenberg The Side Effects of the Legal Process, in The Rule of Law Edited by Robert Paul Wolff (Simon and Schuster New York, 1971) 37.

${ }^{70}$ Note 68 , at 74

71 Note 1, at 159 
intellectually responsible citizens.

\section{A Written Constitutions - The Constitution of the United States ${ }^{\mathbf{7 2}}$}

The written constitution most often quoted and referred to is the Constitution of the United States. This Constitution is reasonably well known. In this paper, various articles and amendments will be used to highlight the difficulties facing a constitution that is set in stone, so to speak and not amendable to change. From this exercise, a comparison of constitutions can be carried out; internal difficulties and nuances within a constitution can be highlighted showing how a government must be committed to democracy, constitutionalism and the rule of law, however, the practices of government need an evolving constitution, to keep pace with a changing society and for that society to remain stable. An evolving constitution is more likely to avoid disruptions being brought by revolutions that can occur in a stagnating society, where the constitution is rigid and difficult to amend.

\section{The Third Amendment ${ }^{73}$}

Written constitutions are often caught up within the time frame in which they were created. For an extreme example of this, consider the Third Amendment of the Constitution of the United States, that prohibits a soldier in a time of peace being quartered in any house, without the consent of the owner; in times of war, the soldier must be quartered in a manner prescribed by law. Whether anyone can assume such a provision may be applicable, in the current political climate with the ongoing 'war on terror' becomes an incongruous question. A soldier, living under this written constitution, were their government to attempt to give effect to the Third Amendment provision would be duly concerned for their wellbeing. That aside, one would have considered this amendment from $1791^{74}$ would have been removed by now.

\section{The Second Amendment ${ }^{75}$}

The Second Amendment of the Constitution has been in the news of late, but more so the second part of the sentence, which reads: "the right of the people to keep and bear arms shall not be infringed." The issue being is whether the people would agree to having greater controls being placed upon their right to own and bear of arms. Again, this Amendment dates back to 1791 . If that provision was simply in an ordinary statute it may

\footnotetext{
72 Otis H. Stephens and Gregory J. Rathjen The Supreme Court and the Allocation of Constitutional Power: Introductory Essays and Selected Cases (W H Freeman and Company, San Francisco 1980)

${ }^{73}$ Amendment III: No soldier shall, in time of peace be quartered in any house, without the consent of the owner, but in a manner to be prescribed by law.

74 Black's Law Dictionary Eighth Edition, Bryan A. Garner (Editor in chief) (Thomson West, ST Paul, 2004) 1775

${ }^{75}$ Amendment II: A well regulated Militia, being necessary to the security of a free State, the right of the people to keep and bear Arms, shall not be infringed.
} 
have been justifiably repealed by now, with the obvious consequence being that many innocent lives would not have been lost.

\section{The Eleventh Amendment ${ }^{76}$ and Sovereign Immunity ${ }^{77}$}

Sovereign or official immunity is the judicial doctrine that a sovereign state cannot be sued without its consent. A nation is sovereign and therefore immune from suit in the courts of any other country. The doctrine comes from feudal England where the lord or monarch could do no wrong. There are public policy grounds for granting immunity to judges and officials in the executive branch. In its current form sovereign immunity extends to both ambassadors and consol.

The extension of sovereign immunity to the individual states, as has occurred with the Constitution of the United States in the Eleventh Amendment, provides for the individual states to be immune from suits by citizens in law or equity. This Amendment removes any access to the law from beyond the reach of individual citizens and abrogates the duties of the individual states to uphold the rule of law in individual cases, except without the states explicit consent. There has been case law that has diminished or reduced the reach of the Eleventh Amendment. ${ }^{78}$

A constitution that operates anterior to the rule of law is inherently problematic. By anterior to the rule of law, I mean that the Eleventh Amendment of the Constitution therefore sits above both the positive laws that are in statute, as well as being anterior to the rule of law, such that the government or state is excluded from the ordinary laws of the land under the doctrine of sovereign immunity. In so doing, the Constitution limits the legal power of citizens as well as the legal power of subjects of any foreign state. Sovereign immunity, that the sovereign can do no wrong, removes the sovereign from the judicative process. As a consequence, while the citizens may develop into intellectually and morally responsible persons, as a result of them becoming capable of deciding and living by the rule of law, the individual states that are not subject to the rule of law, operate anterior to the law, so the laws are not general. The states develop their own laws,

76 Amendment XI: The Judicial power of the United States shall not be construed to extend to any suit in law or equity, commenced or prosecuted against one of the United States by citizens of another State, or by citizens or subjects of any foreign state

77 Above note 74, at 766,

78 Sovereign immunity is a government's immunity from being sued in its own courts without its consent. Congress has waived most of the Federal Government's sovereign immunity. A state has immunity from being sued in federal court by the state's own citizens. See Black's Law Dictionary Eighth Edition, Bryan A. Garner (Editor in chief) (Thomson West, ST Paul) 766. The text of the Eleventh Amendment limits the power of Federal Courts to hear lawsuits against state governments brought by the citizens of another state or the citizens of a foreign country. The Supreme Court has also interpreted the Eleventh Amendment to bar federal courts from hearing lawsuits initiated by citizens of the state being sued and lawsuits initiated by the governments of foreign countries. 
becoming laws unto themselves, so are not governed by the law.

The Constitution places the individual and collective states' judicial power beyond any suit in law and this is a breach of the rule of law: the law is not generally applicable to both the government and the people. There is not a total bar of all lawsuits being brought against state governments. The state can waive its constitutional protection. However, the government cannot be brought into a court of law in suits in equity or law, while the citizens can. Thus, the people will determine that while they can develop into morally and intellectually responsible agents and therefore determine how to live in society as a result or consequence of them adhering to the rule of law, this will not be a universally applied concept to their government, which enjoys immunity from lawsuits. A principle of the rule of law is that all, citizens and state alike, are held to the same juridical ideal. Any state must be able to be held to the same standards and responsibilities as its citizens are. Against this runs the argument that the legislature must be competent to produce the legal consequence or the desired outcome: ${ }^{79}$ so with respect to the Eleventh Amendment, there needs to be the constituent power, with the legislature to be the creature of its own outcomes.

The Constitution of the United States places the rule of law posterior to the positive law that exists in its own Articles and Amendments when it prevents or restricts suits being brought against individual states, either by its own citizens, or foreign states and citizens. The judicial power of the United States extends to bringing suits against both foreign citizens and states alike, but the reciprocal of this, the bringing of suits against the United States cannot be initiated without the government's consent.

\section{Article $V$}

Also of concern is Article V. This article requires any amendment to be passed by two thirds of the Houses, both the Senate and Congress. In reality, Article V affectively removes from the constituents any right to retain the power to create and change the constitution that they initially had, when 'we the people' built the nation and wrote the constitution. The power to exist as a people in a nation cannot be removed nor derogated from: but, without the power to bring a suit against the government and with no opportunity to amend their gun laws nor any other part of their constitution, 'we' the constituents of the United States do not exist as a nation. The constituent power that remains in the nation must therefore exist in its revolutionary capacity only, because it appears absent from the constitution making power.

\section{B An unwritten and living constitution}

A country is said to have an unwritten constitution when there is not a single identifiable document, which is known as that country's constitution. Countries without an identifiable constitutional document still have written constitutions: they exist in

\footnotetext{
${ }^{79}$ Note 9, 374
} 
statute, law reports (common law decisions), conventions, procedures and bills of rights. ${ }^{80}$ A constitution is therefore the general system of laws and customs that comprise of the rules with which a state is governed, and constitute the practices of government. The main issue with an unwritten constitution is where there are no guarantees that rights and freedoms are being protected by the law, as in the case with New Zealand. Unwritten constitutions exist in New Zealand, the United Kingdom, and Israel.

Government practices change. In times of war and during a severe recession (or global financial crisis), there might be much more control on resources, including information, the media, and what the public may or may not partake in. So too, does the constitution change: interests in ecology increase, (and are currently becoming more important); state surveillance of its citizens could become a necessity; different governments are elected and then voted out replacing liberal politics with conservative; also, the expectations that the public has with respect to the freedoms and rights they wish to maintain can come under attack - some rights are lost, while others are gained. These changes require a living constitution that can accommodate a government's duty to govern and maintain a civil society, while at the same time, properly protect people's rights and freedoms from the abuse of power.

A living constitution then, continues to change, maturing with age. ${ }^{81}$ This living constitution is "serviceable to modern needs, while keeping judicial power in reserve for use against patent injustices." ${ }^{82}$ Such a constitution will facilitate democratic reform that facilitates the equal sharing of power and rights. The living constitution will facilitate for the rule of law to be supreme, thus making the rule of law anterior to parliamentary supremacy, when replacing legislative constituent power (the power that the legislature has to change the constitution) with people constituent power. The rule of law, therefore, will determine that the people's constituent power will be anterior to parliament's constituent power. Better an unwritten living constitution, that can facilitate this occurring, which is open to amendment and change, in keeping in touch with the people, that is, the nation and the times. If the question is then, who interprets the constitution, the answer must be, obviously, the people. The people will decide whether or not, as examples, homosexuality is acceptable, or if the Treaty of Waitangi is a founding document, and whether rights to privacy are inviolable.

\section{Constitutional and unconstitutional}

With regards to a constitution that regulates a government, what is constitutional relates to how the polity can be limited and controlled by the practices and customs that the state recognises as being both within the constitution's framework, and external to it.

\footnotetext{
${ }^{80}$ Note 4 , at 17

${ }^{81}$ Sotirios A. Barber and James .E Fleming Constitutional Interpretation: The Basic Questions (Oxford University Press, New York, 2007) 16

${ }^{82}$ Note 81.
} 
These are the formal conventions, rules, procedures, substantive norms, rights and entitlements, which a government recognises as defining what legitimate political activity is - and thus what is constitutional.

With a written constitution, the controls on a polity and thus what is constitutional lie within the written constitution itself, for example, the articles guaranteeing freedom of speech, association, and privacy, or, articles that protect the state from any suit. Hence, with a written constitution, what is said to be unconstitutional are the practices that are in breach or violation of the articles and amendments.

Where the rule of law is being abrogated, or not being fully adhered to, that is with regard to a written constitution, then this is going to be more problematic with respect to addressing the constitutional loss. Such loss will occur, where for example, the state is exempt from a suit being brought against it by the citizens, or by the citizens or subjects of a foreign state, while at the same time, that state can bring a suit against both its own citizens and foreigners. This is supra-constitutionality: states are ruled by laws, the rule of law, but it is not a one way street; the citizens are also ruled by laws, equally applicable to all; and foreigners are also ruled by laws, they can be subject to the rule of law by any foreign states either as visitors or in international law, but when they cannot subject those same foreign states to rule by law, then there can be lawlessness.

However, with respect to an unwritten constitution, the matter is somewhat different. With an unwritten constitution, what is recognised as constitutional are the customs and practices that have evolved over time, and result from an increased recognition by the polity of the rights and freedoms that the public seek to confirm and retain. What appears to be unconstitutional with respect to an unwritten constitution, are the exercises of constitution making that are made by parliament, for which the public is not in agreement, or have not been given a voice on.

Constitutional activity must be both - at the same time - governmental (or political) and popular, that is, what the people believe to be an effective exercise of their constitutional rights. Divergence occurs when constitutional activity is of one kind, for example political, but not concurrently of the other, of the people. Before deciding to change or amend what is in a constitution, the exercise of constitutionalism should be in accordance with the will of the people.

Unconstitutional governmental activity is political activity that still may be democratic, but it is not legitimate activity, as in when the activity is in breach of human rights, freedoms and substantive norms so that the activity does not maintain civil society. For humans to coexist and be happy, they need social stability, which requires state power, and governance. With state power comes a correlating restraint of state power. When such a correlation between state or governmental power and the restraint thereof does not exist, there may be civil unrest or discord. Under this approach of what is constitutional, or unconstitutional, the people according to Locke have a social contract 
with the government, where the government has a fiduciary duty to preserve individual rights, in response to the people being subject to that governmental authority. This is the essential idea of constitutionalism; the rule of law controls both government power and the people who are subjected to the authority of the government. Next is a discussion of the rule of law and how it may affect constitutionalism, when it is placed posterior to positive law.

\section{THE RULE OF LAW}

In an essay titled "The Conspiracy of Law", Howard Zinn speaks of the law itself being as a conspiracy, and how ironical this is, when often the law hounds others as conspirators. ${ }^{83}$ His rather cynical view of the rule of law can be used as an explanation for such consequences as profit in business, power in politics, some efficiency in administration and personal approval by others considered to be 'significant. ${ }^{84}$ All of this can be achieved in modern society, when one obeys the law. But if the onus or emphasis is simply on the general public to live according to the rule of law, including the rules of the land that reduce them to impotency, or suffer the consequences, and not the government who administers the rules, then the wars, poverty, political persecution and alienation are not as a result of the people's preferences, ${ }^{85}$ so these must be the result or work of some 'plot.' ${ }^{86}$ Zinn goes on to say that the law conspires against women's and men's 'equal rights to life, liberty and the pursuit of happiness. ${ }^{87}$

International, national, civil and social stability requires adherence to the rule of law. Whether the stability of a society at one level, say social and civil as an example, needs to be at the expense of stability further up the hierarchy is one point for consideration - South America throughout the 1970's and 1980's is an example of this: or, if the stability that society currently enjoys is being bought at the expense of a forecast for future disorder, and if so, that future disorder will itself be a product of the rule of law, ${ }^{88}$ then, it is all one-way traffic. The advantages of the rule of law, over feudalism and the rule of men, may just be a magnification, Zinn argues, however, the advantages could eventually come in changes to the inequality over wealth and power.

As a concept, the rule of law has been developing and formulating over several hundred years. Napoleon, writing to the King in 1807, extolling the idea of constitutionalism, had a belief in the rule of law, and urged the King likewise. ${ }^{89}$ This is

${ }^{83}$ Howard Zinn The Conspiracy of Law in The Rule of Law Edited by Robert Paul Wolff (Simon and Schuster New York, 1971) 15

${ }^{84}$ Note 83.

${ }^{85}$ At 16

${ }^{86}$ At 16

87 At 16

${ }^{88}$ At 16

${ }^{89}$ At 17 
speaking to what constitutionality actually is; equality in wealth and power, as a byproduct of the rule of law. The exploitation of inequalities that exist in both wealth and power ought to be readdressed in modern formulations of the rule of law.

Rousseau, commenting about the democracy of the British, their form of constitutionalism and whether they are ruled by laws, said that after the elections are complete, the British revert to their "condition of slavery: they are nothing." argument being proffered by the likes of Zinn and Rousseau is that the rule of law supports and operates through the poverty, injustice, racism, sexism, imperial conquest, and oligarchy that are existent in a society. ${ }^{91}$ If adherence to the rule of law is a condition in the public domain only, then it probably needs to be reformulated.

The other side of the coin is that persons have stepped out of the state of nature and into a civil society, to be protected by organised power and this requires us all to be ruled by laws. Anarchy exists in the state of nature, so too, lawlessness, there is no security, nor any personal protection. Now with the anarchy of the past being replaced with organised state power, the only question that remains is what formulation can be given to that organised state power..$^{92}$ Perhaps a future formulation of the rule of law also needs to be considered.

\section{A Formulations of the rule of law}

The rule of law, while an ambiguous concept, is largely seen as a virtue, ${ }^{93}$ but in ordinary parlance the concept refers to the "doctrine that every person is subject to the ordinary law within the jurisdiction." 94 As a concept, the rule of law will depend upon the purpose that it is invoked or used for. Seven usages are: ${ }^{95}$

(a) Government according to law;

(b) The adjudicative ideal of common law jurisdictions;

(c) A minimum of state intervention and administrative power;

(d) The need for fixed and predictable rules of law controlling government action;

(e) Standards of common decency and fair play in public life;

(f) The principles of democracy, freedom and equality; and

\footnotetext{
${ }^{90}$ At 18

91 At 21

92 Note 4 , at 151

${ }^{93}$ Note 4 , at 148

94 Note 74, at 1359

${ }^{95}$ Note 4 , at 148
} 
(g) The fullest possible provision by the community of the conditions that enable the individual to develop into a morally and intellectually responsible person.

For Joseph, there are at least these seven formulations of the rule of law, but lists such as Joseph's can be expanded upon and modified; there are possibilities here. Now, the essential idea is that the government and people work together to develop an egalitarian society. That kind of society is one with a shared belief that "all people are, in principle, equal and should enjoy equal social, political, and economic rights and opportunities." 96 This concept places the government and people on equal footing, with the expectation that, as in (g) above, the government and people together would create a society where both the individuals and government are morally and intellectually responsible for all of their decisions and practices. So, adding to Joseph's list above, would include both an: (h) The Government and citizens have a shared or mutual interest in creating an egalitarian society and each contributes equivalently with their efforts in activities, projects, or undertakings, in the expectation of a shared benefit; and, an (i) Accountability and responsibility for all activity, decisions, misdemeanours and mistakes lies with both the government, local and central, as well as with persons, in whatever capacity they exist.

With (i) a problem might arise with unborn persons, but like all elements of the rule of law, it is the judges in a court of law who have final determination on such issues. Essentially, the idea is that citizens develop into morally and intellectually responsible persons alongside and in parallel with their government's moral and intellectual responsibility - it is unlikely that one will get ahead of the other. There is an expectation that in a modern society a list, such as provided by Joseph above, would become a part of a longer conversation, such that the discussion of ideas around the rule of law and what is needed to create an egalitarian society being encouraged or expanded.

\section{The rule of law in substance}

The rule of law as a substantive legal principle defines rights and duties: ${ }^{97}$ as a doctrine, every person is subject to the rule of law within that jurisdiction; in a constitutional sense, the rule of law means that general constitutional principles are the result of judicial decisions determining the rights of private individuals in the courts; and, the rule of law also refers to a legal ruling on a point of law in a case. In addition, the rule of law exists as a system of control on government behaviour and authority, constraining government behaviour by law (government according to the law ${ }^{98}$ ) and the respect for the law; this is often contrasted with the rule of a despotic, ${ }^{99}$ which is regarded as the opposite of the rule of law.

When respecting the rule of law, states divide the power of government up into

\footnotetext{
96 Note 27 , at 457

97 Note 2, 167.

98 Note 2, 168.

99 Note 1, 780.
} 
separate branches. Civil liberties, importantly the due process of law and the equal protection of the law, are generally protected by the constitution. The rule of law also provides for the transfer of power through democratic elections. ${ }^{100}$ There is a responsibility, said Lord Hope of Craighead, to "define the limits of Parliament's legislative autonomy," placed there by the rule of law, which means that the rule of law is more general, substantive, purposeful. ${ }^{101}$

There are different conceptions of the rule of law, but in the context of restricting governmental power, it can simply refer to how public power gets organised across the three branches of government, the legislature, the executive and the judiciary. There must be some quid pro quo; if the citizens are subject and adhere to the rule of law, and can be held accountable for their crimes and misdemeanours, that willingness to be subject to the law needs to be applicable to their government who are also so required to live under the rule of law. Importantly, the law must be subject to some adjudicative ideal, that is, judicially reviewable, there must be an absence of arbitrary power; the rule of law subjects government power to popular control.

\section{The rule of law in history}

There must be, firstly, a legitimate foundation for the law, which as Locke wrote, is coupled with a fiduciary duty to preserve individual rights ${ }^{102}$ and secondly, there must be some minimum standard of justice, both procedural and substantial. ${ }^{103}$ These origins of minimum standards of justice lie back with the Magna Carta of 1215, the first general declaration of the rule of law ${ }^{104}$ and were a treaty at the time between the King and his people. The Magna Carta is inseparable from the rule of law; ${ }^{105}$ it protected the people against unreasonable search and seizure, against arbitrary punishment and imprisonment, ${ }^{106}$ from being "outlawed or exiled, or disseised of his freehold, liberties or free customs: nor may he be judged or condemned except by lawful judgement of his peers or by the law of the land: nor may justice or right be sold, denied or delayed any man."107

Limits of the royal prerogative were later determined by the Chief Justice, Sir Edward Coke to settle constitutional conflicts with the King, James I. ${ }^{108}$ These limits on

\footnotetext{
100 Note 2, 168.

${ }^{101}$ Note 4, at 148

102 Note 2, at 170.

103 Note 2 at 170.

104 Note 4, at 154

105 Note 4, at 154

106 Note 2, at 172.

${ }^{107}$ Note 4, at 148.

108 Note 2 at 173.
} 
the Crown in Parliament were resolved with the Petition of Rights $1627^{109}$ and the Bill of Rights $1688,{ }^{110}$ completing the transfer of power from the King to the King in Parliament assembled. ${ }^{111}$ What had occurred was "a natural course and direction of the constitution [which] had transformed the legislative power. ${ }^{112}$ The rule of law, therefore, in transforming the legislative power, 'rewrote' the constitution; that seems to be the ongoing role of the rule of law, keeping the constitution relevant.

\section{B The rule of law and constitutionalism}

In opening this section of the paper on the rule of law with excerpts and comments from Zinn's essay about the rule of law, there is the suggestion that not everyone is in agreement upon the role of the rule of law, particularly with regards to constitutionalism. In this section of the paper, I want to discuss the place that the rule of law has in its role in constitution making, particularly, developing the notion from Joseph's list above, of "the fullest possible provision by the community of the conditions that enable the individual to develop into a morally and intellectually responsible person." " constitution must offer and develop some scope for this to occur. The suggestion will be that the development of people as moral and intellectual rational beings occurs when certain elements of the rule of law are present, in what I have referred to elsewhere as the elements of reciprocity, generality, universality, consistency and accountability in a government. When the rule of law is general, the people develop as morally and intellectually responsible citizens because the people see that their government is behaving in a moral and intellectually responsible way - the two, the people and government, develop morally and responsibly, uniformly and in response to each other's decisions and actions.

Constitutionalism means constitutional government and by definition this is inclusive of the rule of law, so constitution making involves the making of a constitution where the rule of law is supreme; this requires replacing parliament as the supreme law maker, with the rule of law as the ultimate principle of legality. Constitution making power is constituent power, that is, the power to make or change a political constitution. Where that power is, or can be found, will depend: The people, the legislature and the executive both contain this constitution making power - they are able to make and change the constitution; It is in renditions of the rule of law, specifically the one described above by Joseph, at (g), and any other future renditions that renders that same power with an organ or body of people that are making the constitution fit for both the government and the people; Constitutionalism, which was limiting government and circumscribing

\footnotetext{
109 Petition of Rights 1627

110 Bill of Rights 1688

111 Note 2,at 173.

112 Note 4, at 155

113 Note 4, at 148
} 
political activity, ${ }^{114}$ is now a work in progress, with the general direction being egalitarianism.

In the past, Parliament, when governing, assessed the public interest, and decided how best to secure it. ${ }^{115}$ However, there has been tension between the government attaining and securing the public interest, when there is a divergence in interests. The rule of law requires adherence to the principles of democracy and constitutionalism, as noted above. Democracy serves political and legal equality, also above. The rule of law mediates between the constituent power that parliament enjoys, which exists in its power to adjust the constitution so that it is able to govern both procedurally and substantially, and popular constituent power, retained by the people. Constituent power is constitution making power: when reflecting upon the role that the rule of law has, it exists in the power to maintain the constitution; it exists with the people, as they determine how to live in a society, allocating in them the power to develop as morally and intellectual responsible persons; there must also exist, in the rule of law, the power to reconcile the divergence with the people's constituent power and parliament's constituent power. How the constitution develops such intellectually and morally responsible persons and government is the project for this immediate discussion. Parliament's power to make constitutional change and the people's power to do the same are mediated by the rule of law, when it stands in opposition to enactments and decisions that might be deemed unconstitutional. Constituent power is as a power encompassing both the polity and people - the rule of law being the essential element and guiding principle - as the people and parliament reconstitute their place and positions in society.

Constituent power is constitution making power, both procedural and substantial, taking the constitution in a natural course and direction, but this same power has an agent in the rule of law, which enables the transforming of the legislative constituent power, thereby resolving any conflict with popular constituent power. The role of the rule of law in this is that the concept sits anterior to positive law, so it directs and control the constituent powers, preventing abuses and excesses, curtailing extremes, mediating in the contest between the legislative, executive and the people. A firm adherence to the rule of law is required, as well as the essential elements of reciprocity, generality and accountability by all parties, including the judiciary - neither can be deemed supreme.

The nation is the rightful possessor of constituent power - and should collectively decide what laws are passed. ${ }^{116}$ Perhaps if there are any standards that can be applied to representative decision making in a nation, it is that the decisions made that create an enactment, where the laws that have been created can both have regard for the equal rights of citizens and uphold the rule of law.

${ }^{114}$ Louis Henkin and Albert Rosenthal, eds Constitutionalism and Rights: The Influence of the United States Constitution Abroad, (Columbia University Press New York, 1990) 1

115 Note 35

116 Note 9, 366. 


\section{The rule of law and the Treaty of Waitangi}

In New Zealand there is a constitutional requirement that includes a recognition of the principles of the Treaty of Waiting (TOW). This is because, as a founding document, the Maori version of TOW provided for sovereignty of the Maori people. One argument is that the rule of law requires the Crown to recognise the TOW as the founding constitutional document, between Maori and the largely English settlers, because that is what is expected of the Crown in the agreement that was signed with Maori. If looking for the element of the rule of law that is missing in the Treaty of Waitangi, then it may be found in the Crown's recognition and commitment to the sovereignty of the Maori people. Maori cannot be bound by an application of rule of law to the Treaty of Waitangi that excludes or diminishes their sovereignty.

The Maori version of the Treaty of Waitangi guaranteed the sovereignty of the Maori people and a constitutional country like New Zealand would be expected to adhere to the rule of law, to give effect to the words as they appear in a founding constitutional document. When the rule of law is broken, as has occurred with the Treaty of Waitangi, so too is the original contract between the Crown and the Maori people. ${ }^{17}$

\section{The rule of law in New Zealand}

In New Zealand law that the legislature creates is supreme. This includes legislation that is in breach of fundamental rights; there exists here, therefore, a tension between the rule of law and "untrammelled legislative power." 118 A contest and tension exists then, between the rule of law and the rule of parliament, as to which is supreme; this remains unresolved and requires mediation. One argument is, that if the elected representatives in a parliament have considered breaches to fundamental rights, and determined that the legislature is still supreme, then, the representatives do not recognise the rule of law; alternatively, the executives who are the power behind the throne, so to speak, have determined then, that it is necessary for fundamental rights to be abrogated, in certain situations and have convinced the people's representatives in parliament accordingly. The rule of law, which subjects all parties to rule according to the law, is therefore inconsistent with the sovereignty of Parliament, that speaks of untrammelled legislative power.

Joseph, writing on Dicey and this tension between parliament and the rule of law, acknowledged this problem. He referred to the "mysteriously internalised ... tension with its admonishment"119 in the Supreme Court Act 2013, where it states: "Nothing in this Act affects New Zealand's continuing commitment to the rule of law and the sovereignty of New Zealand." 120 This indicates a deliberate subversion of the rule of law to the

\footnotetext{
117 Note 2, 174.

${ }^{118}$ Note 4, 152

${ }^{119}$ Note 4, at 152

120 Supreme Court Act 2003 s 3 (2).
} 
sovereignty of New Zealand.

Democracy requires representative government. In New Zealand, part of our unwritten constitution requires that the government enacts legislation that respects and is committed to the rule of law. The problem is, of course, when the rule of law cannot be sustained or confirmed within an enactment, then, as is indicated in the Supreme Court Act 2003, the rule of law is only in the form of a commitment and may not be absolutely necessary. An unconstitutional enactment or an enactment that includes sections or clauses that are in breach of the rule of law, for example equal treatment before the law, may still receive royal assent. Parliament is still sovereign, and can pass any legislation that it pleases, and more easily so with an unwritten constitution. There is a concern though, that a parliament would place the rule of law in a statute as a principle that the state is committed to. Joseph does note that it is "odd" for such a provision to be placed in the Supreme Court Act 2003 because the Act should not be able to affect the "fundamentals on which the constitution is based." 21 However, it can. Parliament appears to have placed the application of the rule of law posterior to the operation of positive laws. ${ }^{122}$

\section{The rule of law and Parliamentary Supremacy}

As a principle, the rule of law is applicable to both parliament and the courts, the important factor being where and by whom will the principle be applied. If and when parliamentary supremacy is surpassed by the rule of law as the ultimate principle of Westminster legality, ${ }^{123}$ then the constitutionality of the society will be retained where civil society is maintained and rights and freedoms are vouchsafed. By this I mean that the constitution making power will shift to wherever the rights and freedoms and civil society are being maintained the best, by the organ or part that is doing the most to protect civil society and individual rights. Inevitably, that will end up as the court's role, when they determine to uphold the rule of law.

Today's contest or tension with respect to the rule of law is between the democratically elected parliament and the people, whether or not their rights are upheld by the courts. Previously, the right to rule as a prerogative power, was fought between the King and Parliament, when the King believed that as an individual he (sic) alone had the right to rule, ${ }^{124}$ as the supreme arbiter of law. As a result of the Glorious Revolution, no taxes could be levied nor any legislation passed without the authority of Parliament. Parliament was supreme. The issues remains, can the rule of law define the limits of Parliament's legislative supremacy, and what will be the effect of any limiting of

${ }^{121}$ Note 4,153

${ }^{122}$ Note 72 , at 12 . Stephens and Rathjen suggest that the constitution is a top of the hierarchy of law. One interpretation is that the constitution is anterior to positive law, and anterior to the rule of law.

${ }^{123}$ Note 4, at 152

${ }^{124}$ Note 4 , at 153 
parliament. Previously, the courts gave away the contest with parliament for supremacy, seeking instead to focus on protecting individual rights. Now that contest between limiting parliament's power and protecting individuals is back before the state, the determination of this matter will resolve who rules the nation, either parliament or the rule of law. The answer is probably this one: a rendition of the rule of law that is suited to developing morally and intellectually responsible persons in conjunction with their government will evolve as the ultimate principle of legality.

The rule of law will challenge parliamentary supremacy as the ultimate principle of legality, as this will resolve the issue of where the constituent power lies. This may occur when a statute clearly breaches rights and freedoms, then the principles found in the rule of law will result in the rule of law becoming supreme over statute. Under the Act of Settlement 1700 (Eng) "[t]he judges conceded the supremacy of statute over the common law but turned their attention to securing the individual from official interference or abuse." 125 The famous case of Entrick $v$ Carrington again secured the individual from official interference rejecting the argument for state necessity. Therefore, this is where the challenge to parliamentary supremacy will be, where individual rights and freedoms have been abrogated, the rule of law will determine that such laws that abrogate rights cannot be upheld; the law is a general principle that is applicable to all, thus determining that the rule of law has supremacy over statute law.

\section{The rule of law, or, as a necessity of the Right of the House}

With colonial legislatures, such as New Zealand, the test of necessity circumscribed the privileges of the House of Representatives; in other words, as a necessity, there were no limits on parliamentary privilege - as per the laws and customs of parliament (lex et consuetudo parliamenti) resulting in parliament's privileges being said to be unique and egocentric. In order to pass all the laws necessary for the peace, order and good government, ${ }^{126}$ parliament must be deemed by the 'customs of the realm' and laws to have all of the powers inherent in the Houses of the British Parliament, including those powers at common law, as an example, contempt of the legislature. The contempt power, (despising the authority or dignity of the legislature) is one of the powers necessary for the authority of the legislature, necessary for the complement of its functions, and includes the power to commit or imprison for contempt of parliament, and is a further example of parliament being a judge in its own cause. ${ }^{127}$

Parliament, as the House of Representatives, is the sole judge of its own proceedings and powers, and this judicial function, while also accounting for its egocentricity, is deemed essential to fulfilling its functions and its authority. The House of Representatives enjoys unlimited rights, powers and privileges, "without which it

\footnotetext{
${ }^{125}$ Note 4, at 157

${ }^{126}$ Note 4, at 405

${ }^{127}$ Note 4, at 406
} 
could not discharge its functions" 128 and because these privileges are a part of the constitutionality of parliament, to a certain extent that parliament is exempt from the general law of the land. ${ }^{129}$ The origins of these privileges of the House date back to the struggles that it had with the Crown and then the courts, as the House asserted its independence and authority. These laws and customs of parliament are a general reference to the fact that as a custom and from the common law, parliament is accustomed to doing whatsoever it needs to do, to fulfil its functions. If parliament was once, to a certain extent exempt from the general law, then it remains uncertain as to whether it will also remain so exempt from the general law, including the rule of law; when it comes to what is constitutional with regard to legislation that can be enacted, the only fetter that parliament has over the control of its power, is that fetter that parliament itself exerts. That control that exists over parliament is changing.

That somewhat dated struggle for the House, where it asserts its independence and authority, must nowadays be called into question with respect to what might be considered as legitimate activity and whether the House is exempt from both the general law and the rule of law. The peculiar rights enjoyed by the House are said to exceed those which are possessed by other persons, or bodies or individuals, ${ }^{130}$ but the extent that these rights are exempt from the general law and the rule of law remains unresolved.

The House enjoys the right to be the sole judge of its own proceedings. Anything arising or concerning the House cannot be examine, discussed or adjudged, according to Blackstone, elsewhere. ${ }^{131}$ However, that right was created vis a vis the House's struggle with the Crown and the Courts, and arguably since the Glorious Revolution that struggle no longer exists with the Crown, and it is wholly questionable as to the extent of the ongoing struggle with the courts. With the rule of law constraining the law of parliament, the House will no longer be the judge in its own cause, in so doing, the rule of law will bring forth the ideal of an egalitarian society.

In the following section, I want to confine this discussion, to determine the limits of parliamentary supremacy, thereby answering the question 'where the constituent power must now lie, whether that power is being returned to the people' and therefore who determines the content and direction of a nation's constitution. The power of nationhood has always been with the people, and while the elected representatives are chosen to make decisions on their behalf, the crux of the matter being, their decision making must exist as a by-product produced to assist with the citizens becoming morally and intellectually responsible, alongside their government. This can only be brought to fruition in conjunction with the government also acting in morally and intellectually responsible ways. What remains to be seen in the resulting nation building, is how these

\footnotetext{
${ }^{128}$ Note 4, at 401

${ }^{129}$ Note 4, at 401

${ }^{130}$ Note 4, at 401

${ }^{131}$ Note 4, 439
} 
respective forms of constitutionalism, the written and unwritten, best fulfil the role of returning to the people the rule of law. The example used will refer to the Constitution of the United States and the unwritten constitution of New Zealand.

\section{DEMOCRACY, CONSTITUTIONALISM AND THE RULE OF LAW: BEHOLDEN TO CONSTITUTENT POWER}

Individually, the three separate components, democracy, constitutionalism and the rule of law, are incomplete. Each of the three components is powerful, in its own right, but, these are posterior to constituent power. ${ }^{132}$ Otherwise, as Colon-Rios said, "sovereignty would have been taken away from the people, and given to their representatives." 133 When locating constituent power with the people, and describing it as the constitution making power that directs constitutionalism, granting the people the capacity to act and exist as morally and intellectually responsible citizens, any legislative, executive or judicial decisions that detract from such a power, would be decisions that are supra-constitutional, and so are ancillary to a revolution, because the decisions are abrogating the rule of law. Supra-constitutionality, therefore, places the constitution anterior to the rule of law and anterior to constituent power; this is a place where the constitution can no longer exist on its own without it being an absolute power, because it is in tension or opposition to the nation.

These three components, democracy, constitutionalism and the rule of law, when related to each other, because of the rule of law and constituent power, require the government to self-regulate its power. In part this is because of the constitution but mainly because when the people decide for example that they want to live in an egalitarian society, so, too, must the government agree with the people. Also, that same constituent power (that power to make constitutional decisions) is also binding upon the democracy, constitutionalism, and the rule of law, limiting government and circumscribing political authority, but its essence is in the rule of law, as it determines to replace parliamentary supremacy as the ultimate principle of legality. ${ }^{134}$ Following the maximum ubi jus ibi remedium (where there is a right there is a remedy): ${ }^{135}$ in democracy there is a right to vote, for which there is a remedy; in constitutionalism exists substantive rights and freedoms, the remedy of which is discussed below in a comparative constitutional law context; and, with the rule of law there is incarnate the right to justice, but in the New Zealand context there is no absolute guarantee of a remedy, with there being only at best a 'continual commitment' to the rule of law, as it is posterior to positive law.

A democratic government is considered to be one that is guided by its constitution

\footnotetext{
132 Note 8,371

${ }^{133}$ Note 8, 371

134 Note 4, 152

${ }^{135}$ Note 4, 407
} 
and this requires adherence to the rule of law. The rule of law is the corner stone and guardian of any constitution. This legal and political ideal has three important posits: liberty of the individual; equality before the law; and freedom from arbitrary interference in a community (by the government). Equality before the law is inclusive of both common law and statute. The power of a constitution, therefore, is in its ability to preserve both equality, liberty, and the nation: this is constituent power and nowadays lies with the morality and intellectual responsibility; understandably this power is with the people, as a nation. That power is retained by the people, when excesses in governmental power seek to limit the constitution, against the will of the people and is the result of the people acting morally and responsibly. Governments, then, in a future rendition or formulation of the rule of law, in an egalitarian society, will mediate between the power and wealth that they have and that of their citizens, in an attempt to produce an equilibrium, where power, morality, wealth and responsibility are shared. It should not all end up in one corner, say with the lawyers - nor the politicians, for that matter.

There is similarly constituent power that results from the democratic process when representatives are elected, the power that those elected representatives have to make constitutional changes, as a part of the process of law making, when re-addressing constitutional matters. Constituent power, which can also be termed the power to change the constitution, therefore, is in three places: it exists with the legislature who create and change constitutional laws, that affect the constitution and pass them through the house of representatives to become statutes that are binding on its citizens; also, constituent power exists with the people, who retain enough power to take back their rights, as Locke once said; ${ }^{136}$ and, with the executive, who assist the legislature when determining decisions on public policy concerning matters that affect human rights and ultimately the rule of law, so here too, there is arguably also some residual constituent power.

Governmental constituent power, which is often the product of the democratic process, and people constituent power, what is retained after the elections, in part because of the constitution, often diverge; these two elements, government or democratic constituent power and people's constituent power, under the concept of the rule of law, converge back together, returning to individuals their rights, and restraining the government from altering the constitution in ways that may be an abuse of power. The rule of law is therefore the element that would restrain political power. However, if political power is absolute, were parliament to be truly sovereign, and when the rule of law is posterior to positive laws, then the place that a constitution has constraining the excesses of government is diminished, even removed.

Juridical norms ${ }^{137}$ exist in the nation. And this is where the constituent power is. By juridical norms, I mean in a nation there exists a set of juridical norms, rules and laws

136 John Locke "The Extent of the Legislative Power" (Chapter XIX, The Second Treatise of Government);

"Of the Dissolution of Government" section 220.

137 Note 9, 366. 
that the people, when retaining constituent power, do not relinquish, unless they so choose. In effect and in reality, the people decide what laws they do and no not want to enact. So, there exist some constraints on what types and kinds of legislation parliament can enact. There exists a body of laws that cannot, or should not, be passed through parliament and the reasoning for this is that it would be unconstitutional to do so; a government would not want to pass any laws through the House of Representatives that its citizens do not want to see enacted. Examples of this are laws that breach fundamental rights and liberties, that restrict freedoms such as that of speech and assembly, and that allow the government unlimited powers.

\section{A The Constitution of the United States}

A written constitution, such as exist in the United States, needs to be ameliorable to change, keeping itself relevant and therefore retain the contract with the people that exists as a result of them coming out of nature, and forming themselves into a nation state. In doing so, the constitution will bring confirmation as to where the constituent power exists. Coupled with confirming constituent's rights, is the constitution's core role of regulating government, both procedurally and substantively. For the people of the nation to develop as morally and intellectually responsible beings, and for the society to progress towards egalitarianism, both the polity and the people must be held to the same general laws and principles; both people and polity would be subject to the same standards of the rule of law and, equally both the government and the people equally are susceptible to the judicial processes, in the ordinary courts of the land.

Jurisdictions that have written constitutions that consist of a supreme law bill of rights, such as the United States, have an inherent provision for the enforcement of constitutional rights to be placed above statutes that might derogate form rights; fundamentally, "this embodies the principle of "rule of law." 138 The United States, for example, has a constitution that is the source of all power. In Article III the judicial powers extends to all cases both in law and equity that arise under the constitution. ${ }^{139}$ Article III allows for judges to judicially review statutes for inconsistency with fundamental rights under the rule of law. ${ }^{140}$ Under Article VI, the constitution has a supremacy clause that "places the constitution at the top of a hierarchy of law." ${ }^{141}$ Noted above, in the Eleventh Amendment, the judicial power of the United States does not extend to suits in law and equity, against the states; the constitution places the law beyond the reach of individuals and foreigners. Article III and the Eleventh Amendment appear to be in direct conflict with each other. The constitution is above statute law, anterior to the rule of law.

\footnotetext{
138 Note 71,12

139 Article III, Section 1: The judicial Power of the United States, shall be vested in one supreme Court, and in such inferior Courts as the Congress may from time to time ordain and establish...

140 Note 71,536

141 Note 71, 12.
} 
Absent the same juridical ideal, constituent power will only lie with the legislature and executive. To restore constituent power, the people would resort to a people's revolution. As Thomas Jefferson said, every nation needs a revolution from time to time. Better one in the nation's constitution, initiated and carried out by the government, than one as the result of some supra-constitutionality, because the constitution was superior to the rule of law, and superior to constituent power.

\section{B The Constitution of New Zealand}

The rule of law should not be posterior to positive law, as I suggest that it is the current case. At least, it appears to be. Others might disagree; Palmer, as quoted, would like to see a greater adherence to the rule of law, and Joseph sees it eventually replacing parliamentary supremacy. Parliament relies on popular sovereignty, their authority is sustained upon the consent of the people, and while the people are willing to abide by the rule of law, so too must the government be willing to do the same. Egalitarianism won't appear by chance, nor good fortune - it is a principle parliament would do well to pursue.

Lastly, below I outline in a comparative constitutional context, how constitutions can be amendable to change. For Part VI, I again assume that the government is committed to democracy, constitutionalism and the rule of law.

\section{COMPARATIVE CONSTITUTIONAL REVIEW}

A comparison of methods of constitutional review between jurisdictions that have written and unwritten constitutions will enable one to distinguish how different states resolve issues of unconstitutionality. Arguably, in New Zealand, there is little or no scope to address what might be regarded as unconstitutional law; the rule of law has the form of a continual commitment, the BORA is not supreme law, so is subject to reasonable limitations, and any substantive norms are not denoted or observed in any respect in the constitution. There is no judicial review of legislation. Because the people are always committed to both the rule of law, constitutionalism, and democracy, so too must the government be also equally committed, but to retain that commitment requires a constitutional moment; the people are required to abide by the rule of law, and here the divergence exists, the government only has a continual commitment to the rule of law, which can exist posterior to positive law so the government can legislate in breach of freedoms, rights and substantive norms. A comparison across jurisdictions of how reviews of constitutionality are conducted in the courts will give some insights to assist with the New Zealand position on this point, in an attempt to provide an option to alleviate against democratic loss and address abuses of power by governments.

Two models of constitutional review exist, the difference in them being in the organisation of the system used. Constitutional review provides a basis for determining the divergence of constituent power, where the written charter of government, 
representing constitutionalism, ${ }^{142}$ enables a limiting of government and circumscription of political authority, which is seen to be digressing or diverging from the rule of law, and includes the protection of rights and freedoms, with the recognition of substantive norms. These two models enable states to resolve issues around the unconstitutionality of legislation and the divergence of constituent power - the power that each the legislature, executive and people holds that forms together in the constitution, so constitution making power.

Broadly speaking, the Europeans and the Americans use models of constitutional review that "protect fundamental rights against infringement by governmental authority, particularly the legislature" 143 but also the executive. These two options are discussed below, and work well where the courts are able to separate the power that the legislature has, when unconstitutional legislation is reviewed and appealed. There is also constituent law making power that the executive possesses, when it works with the legislature in many jurisdictions, making proposals for legislative and substantive constitutional change. A further form of constituent power exists where the courts in their review of the constitutionality of legislation, can also divide the chambers of power, in a bicameral parliamentary system, therefore again separating the powers that exists in the legislature.

The French use a constitutional council, ${ }^{144}$ which has developed since its inception into a body that can raise issues about the constitutionality of laws, and is the model that this paper will develop for use in the New Zealand context. Because there is no check on the constitutionality of legislation that is produced and passed in the New Zealand Parliament, the discussion needs to now turn to how that issue might be resolved.

\section{A Constitutional review in the courts}

The two broad types of judicial control exist over the constitutionality of legislation, are the decentralised and the centralised models. ${ }^{145}$ The American system of control is the decentralised type of judicial review of legislation, where the power of control over legislation is given to the judicial organs of the legal system. In America judges can strike down legislation that is unconstitutional. This decentralised system lodges constitutional review in the judicial system as a whole, so that there is no distinction between the judicial review of legislation and the administration of justice generally. ${ }^{146}$ Disputes are decided by the same courts, whether or not the disputes are of a constitutional matter, using the same procedures and in similar circumstances. The decentralised type of judicial review of legislation works well when there are common law cases to be brought before the court. The court's review of a constitutional matter

\footnotetext{
142 Note 67, at 1

143 Note 67, at 41

144 Note 67, at 53

145 Note 67, at 41

146 Note 67, at 41
} 
results in "a judgement limited in principle to the case decided;" if this is made in a Supreme Court then that decision has general authority for all courts.

The second type of judicial control is the centralised type that confines the power of review of the constitutionality of legislation to one single judicial organ ${ }^{147}$ Litigation that is constitutional is distinguished from that which is criminal or commercial and is decided in its own constitutional court. A court is especially established for the purpose of deciding the matter "and enjoy a monopoly on constitutional litigation." 148 The constitutionality of a matter is therefore decided in the abstract. However, as above with the decentralised type of control over judicial organs, if the state is not being run by the rule of law, then a constitutional court may also be subverted by the interests of the state, thus abrogating any constitutional rights.

A constitutional commission, as proposed and discussed below could assist in resolving this issue, because it would take a decision that is reachable by the courts, and place it back before commission. There has to be a guarantee of fundamental rights, including the right of equality, and a power of judicial review of legislation to which there is public access for the doctrine of the separation of powers to be fully realised; Parliament's explicit enactment of unreasonable limitations of rights (on a small range of cases) is in breach of the rule of law. ${ }^{149}$

\section{B The French Constitutional Council}

France has a Constitutional Council, established in 1958, composed of nine judges, which has jurisdiction over electoral issues, and referenda. ${ }^{150}$ Former French presidents are de jure members of the Constitutional Council, although none have sat since 1962. The French Constitutional Council also has jurisdiction over "conflicts regarding division between the legislative domain and regulations ... the constitutionality of the rules of a chamber of Parliament ... the constitutionality of international treaties ... and the constitutionality of laws." 151 The jurisdiction of the French Constitutional Council over the constitutionality of laws is "upon request of the four highest authority of the state (the president ... chairman of the national assembly and of the senate, and the prime minister), or by sixty members of the national assembly or sixty members of the senate." 152 The French Constitutional Council has via a process over the years since its inception developed into an arm of government that is be able to constitutionally "review laws challenged as being beyond the authority of parliament." ${ }^{.153}$ Other electoral issues,

\footnotetext{
${ }^{147}$ Note 67 , at 41

${ }^{148}$ Note 66 , at 41

${ }^{150}$ Note 67 , at 53

${ }^{151}$ Note 67, at 53

152 Note 67 , at 53

${ }^{153}$ Note 67, at 53
} 
(whether or not they are unconstitutional), still remain under the Constitutional Council's oversight. The laws are also still subject to the review by the courts. The courts just choose to respect the Constitutional Council's decision. Members of Parliament can use their power to raise "constitutional issues before the Constitutional Council, and its case law has become an important factor in France's legal and political system." 154

\section{New Zealand Constitutional Commission}

In New Zealand, the Electoral Commission has a corresponding jurisdiction over elections and referenda, which is similar to the French Constitutional Council, above. A natural extension of the Electoral Commission to look something akin to the French Constitutional Council, so to include other electoral issues, and address issues around the constitutionality of laws, thus making it into a New Zealand Constitutional Commission is a proposal that could be considered. The Constitutional Commission would be able to recommend parliament does not adopt a law, thus increasing the separation of powers between legislature, executive and the judiciary. Currently, decisions of the Electoral Commission can be judicially reviewed in the ordinary courts. The new Constitutional Commission would also be subject to judicial review by the ordinary courts of the land. In France, constitutional rules are reviewed by the Court of Cessation. ${ }^{155}$ Similarly in New Zealand, the work of the courts would be extended to include the judicial review of laws.

A request by a requisite number of Parliamentarians, either from the coalition in opposition or the coalition in power, to the Constitutional Commission, over the constitutionality of a bill (or statute) would begin the process of reviewing the legislation for constitutionality. The members of the Constitutional Commission would look at the constitutionality of the bill or law in question, consider its constitutional significance, and determine whether or not a larger conversation is needed. The matter may simply be referred back to Parliament (which could become the subject of a judicial review in the ordinary court procedure, brought by the members of Parliament that initiated the process) or, it could become some small debate, amongst interested constituents. More robust debate may be needed for more significant constitutional matters.

The Constitutional Commission would therefore perform a judicial function over the legislature and the proceedings of parliament, somewhat like the example in the comparative French Constitutional Council, to determine whether the bills being produced are unconstitutional, as both a substantive and procedural matter and in accordance with the rule of law. The rule of law also has a substantive quality, where what is expected from the legislature is to uphold principles, such as freedoms and equality, as discussed above. The Constitutional Commission will determine constitutional matters, with regards to the procedural and substantive enactments of

\footnotetext{
${ }^{154}$ Note 67 , at 53

${ }^{155}$ Note 67, at 53
} 
parliament. An action for breach of the rule of law must also be able to be brought against an enactment directly through the courts.

The current jurisdiction of the Electoral Commission would remain, including where the Commission is subject to judicial review in the High Court of New Zealand. The development of case law in this area is much needed, as the constitutional framework that protects rights and freedoms currently is lacking. As a comparative example, a revised Electoral Commission would look somewhat similar to the French Constitutional Council, and could be named as the New Zealand Constitutional Commission.

\section{Democratic loss, constitutional review, and the rule of law}

A convergence in the various models of constitutional review could be realised if the different states produced similar amounts of democratic loss, but by different methods. The ideal or notion of constitutional review is how to limit governmental power, in order to reduce the confrontation or power struggle that exists between the judge and legislature, as a result of the review of unconstitutional legislation. Reducing this confrontation between judge and legislature in New Zealand would best be achieved in a two stage system; a Constitutional Commission that is subject to ordinary judicial review would bring about the desired result. This two stage system would adequately reflect the unique conception of the separation of powers that exists in New Zealand. A model needs to be created whereby the constituent power of the legislature, executive and judiciary are adequately monitored, so reflecting New Zealand's unique political system.

Constitutions that limit governments are favoured by the people. The people are sovereign; they elect governments or give elected officials authority, to decide matters which are in their best interest. Governments, however, often prefer collective preferences over the individual preferences of its citizens, and this is also where the loss in democracy occurs. There exists, therefore, a tension between democracy and constitutionalism, between the democratically elected government exercising its constituent power, and the human rights that the people have gained, for example, back in the Magna Carta of $1215 .^{156}$

What is envisioned under the constitution is mutual agreement, with regards to human rights. That is, a democratically elected government would hold a dialogue with regards to what rights the people would like to hold onto. Thomas Christiano ${ }^{157}$ was thinking along these lines. He envisaged an agreement, with respect to rights that followed some discussion, a degree of autonomy. Mauricio Garcia-Villegas, ${ }^{158}$ writing on constitutionalism, protecting rights and the avoidance of abuses of powers, theorises that

156 Magna Carta 1215, revised and reissued in 1216 and 1217.

157 Thomas Christiano "Democracy" (2007) in Stanford Encyclopaedia of Philosophy $<$ http://stanford.library,usyd.au>

158 Maurico Garcia-Villegas "Law as Hope: Constitutions, Courts, and Social Change in Latin America" (2004), p 8. 
when a government is acting unconstitutionally, what is being produced is a process that allows the government to legitimise its enactments.

Colon-Rios ${ }^{159}$ discusses the use of the constituent power of the people, and concludes that constituent power is unlimited: at least not legally. Constituent power can both limit legal power and justify unlimited political power, but that power, constituent power that is, itself cannot be limited. The sovereign power, either parliamentary or popular or executive, has to 'change, create or transform a constitution.' No doubt, there must also be scope for the people retaining and using effective constituent power and an argument exists for the people's constituent power, absent a supreme law bill of rights and judicial review of legislation.

\section{CONCLUSION}

The tension in a democracy is because not all of the peoples' personal preferences are measurable, and there will be differing motivations for making political choices. Constitutionalism dictates different ways of regulating, founding and formulating a government, with the main idea being that the government and the constitution both equally affect each other. One location for finding constituent power is in the rule of law, assuming of course, that the rule of law is not posterior to positive law; constituent power maybe in transition. An important consideration is how to re-spread the constituent power between the government, the people and the executive; this may require an additional arm, in a Constitutional Commission.

Constituent power can both limit governmental power, and prevent limits being placed on that power by the constitution. The nation is the bearer of constituent power, and does not need anything other than its own existence to be legal. ${ }^{160}$ While individually the components may be in tension with each other, this paper shows how the process of creating and maintaining a stable government can occur, when the individual components are respectful of each other. An egalitarian state will be democratic, constitutional and adhere to the rule of law.

\footnotetext{
159 Above, note 9, 365 .

160 Note 9, 366.
} 


\section{Bibliography}

I PRIMARY SOURCES

A Legislation

Magna Carta 1215, revised and reissued in 1216 and 1217

Petition of Rights 1627

Bill of Rights 1688

New Zealand Bill of Rights Act 1990

Supreme Court Act 2003 s 3 (2).

International Covenant on Economic Social and Cultural Rights (opened for signature 16 December 1966, entered into force 3 January 1976) Articles 9 \& 11.

Constitution of the United States Article V, Amendments II, III, and XI

SECONDARY SOURCES

\section{A Books}

The Oxford Companion to Philosophy, edited by Ted Honderich, (Oxford University Press, New York, 1995).

Philip Joseph Constitutional and Administrative Law in New Zealand (The Law Book Company Limited, Sydney, 1983).

Philip Joseph Constitutional and Administrative Law in New Zealand (The Law Book Company Limited, Sydney, 2007).

Black's Law Dictionary Eighth Edition, Bryan A. Garner (Editor in chief) (Thomson West, ST Paul, 2004).

Concise Oxford Dictionary Eleventh Edition (Oxford University Press, New York, 2004).

Kenneth J Arrow, Social Choice and Individual Values (John Wiley and Sons, Inc, New York, London 1951).

Sotirios A. Barber and James .E Fleming Constitutional Interpretation: The Basic 
Questions (Oxford University Press, New York, 2007).

Barbara Cruikshank The Will To Empower: Democratic Citizens and Other Subjects (Cornwall University Press, New York, 1999).

Anthony Downs, An Economic Theory of Democracy (New York, Harper, 1957).

Ronald Dworkin Freedom's Law: The Moral Reading of the American Constitution (Harvard University Press, Cambridge, 1996).

Ronald Dworkin Is Democracy Possible Here? Principles for a New Political Debate, (Princeton University Press, New Jersey, 2006).

Stephen L. Elkin and Karol Edward Soltan A New Constitutionalism: Designing Political Institutions for a Good Society (University of Chicago Press, Chicago, 1993).

Edgar Z Friedenberg "The Side Effects of the Legal Process," in The Rule of Law Edited by Robert Paul Wolff (Simon and Schuster New York, 1971).

Louis Henkin and Albert Rosenthal, eds, Constitutionalism and Rights: The Influence of the United States Constitution Abroad, (Columbia University Press New York, 1990)

Otis H. Stephens and Gregory J. Rathjen The Supreme Court and the Allocation of Constitutional Power: Introductory Essays and Selected Cases (W H Freeman and Company, San Francisco 1980).

Howard Zinn "The Conspiracy of Law" in The Rule of Law Edited by Robert Paul Wolff (Simon and Schuster New York, 1971).

\section{B Articles}

Joel I. Colon-Rios "Carl Schmitt and Constituent Power in Latin American Courts: The Case of Columbia and Venezuela" (2011) 18 Constellations.

Joel I. Colon-Rios Notes on Democracy and Constitution-Making, (9)1 New Zealand Journal of Public and International Law.

John Locke "The Extent of the Legislative Power" (Chapter XIX, The Second Treatise of Government); "Of the Dissolution of Government." section 220.

Martin Loughlin, "Constituent Power Subverted: From English Constitutional Argument to British Constitutional Practice in Martin Loughlin and Neil Walker (eds) The Paradox 


\section{Democracy, Constitutionalism and the Rule of Law:}

of Constitutionalism, (Oxford University Press Oxford 2007).

Carl Schmitt Constitutional Theory (Duke University Press, Durham, 2007).

Andras Sajo "The Taming of Democracy" in Limiting Government: An Introduction to Constitutionalism (Central European University Press, Budapest, 1999).

Jeremy Waldron "The Constitutional Conception of Democracy" in Law and Disagreement (Oxford University Press, New York, 1999). 